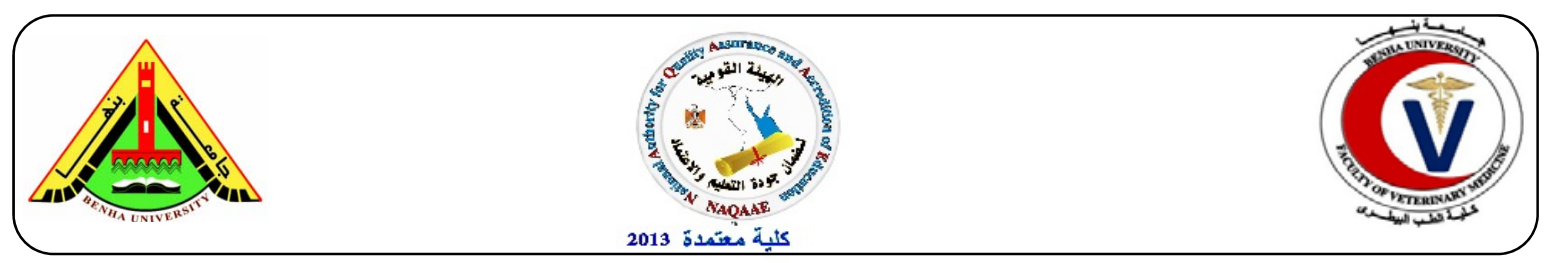

\title{
Incidence of $E$. coli in some meat products
}

\author{
Fatin M. Hassanien ${ }^{1}$, Shiamaa M. Nada ${ }^{2}$, Alaa M. Abd-Elsattar ${ }^{2}$ \\ ${ }^{1}$ Department of Food Control, Faculty of Veterinary Medicine, Benha University. ${ }^{2}$ Animal Health \\ Research Institute, Shebin- Elkom Branch.
}

\begin{abstract}
A B S T R A C T
A grand total of 100 random samples of meat products represented by beef burger and kofta ( 50 of each) $100 \mathrm{~g}$ were collected from different shops and hyper supermarkets in different districts in Menofia governorate. The incidence of $E$. coli in the examined samples of meat products were $28 \%$ and $36 \%$ for beef burger and kofta, respectively. Moreover, the isolated serotypes of $E$. coli from the examined samples of meat products were $O_{26}: H_{11}, O_{86}, O_{55}: H_{7}, O_{104}: H_{4}, O_{111}: H_{4}, O_{114}: H_{21}, O_{119}: H_{4}, O_{124}, O_{125}$ : $H_{21}, O_{167}: H_{21}$ and $\mathrm{O}_{128}: H_{2}$ with various percentages, Also, application of sensitivity test on all E. coli strains indicated that most of them were multiple antimicrobial resistance (MAR) where the MAR index equal 0.515 . The public health significance of the isolated organisms from meat products was discussed as well as some recommendations to ensure safety and quality of meat products reach to consumers.
\end{abstract}

Keywords: E. coli, Meat Products, Multiple antimicrobial Resistances.

(http://www.bvmj.bu.edu.eg)

(BVMJ-30(1): 104-108, 2016)

\section{INTRODUCTION}

$\mathrm{M}$ eat is considered as an essential food, tasty, from the beginning a commitment to sanitation is a must. The remaining part was processed in order to preserve the meat for later consumption. Processing meat to meat products is away to preserve meat. Meat processing plants have a significant variation in degree of sanitation. Construction of facility for ease of sanitation and proper equipment must be available to employees to ensure successful completion of sanitation objectives (Saleh et al., 2012). In Egypt, meat products such as kofta and beef burger are gaining popularity as they represent quick easily prepared meat meals and solve the problem of the shortage in fresh meat of high price which is not within the reach of large numbers of families with limited income (Shawish 2015). Actually E. coli is commonly non virulent but some strains have adapted pathogenic or toxigenic virulence factors that make them virulent for man and animals (Malik and Memona, 2010). These pathogenic E.coli strains include enteropathogenic (EPEC), enterotoxigenic (ETEC), enteroinvasive (EIEC), enteroaggregative (EAEC), diffusely adherent (DAEC) and enterohemorrhagic (EHEC) types, of which E. coli $\mathrm{O} 157: \mathrm{H} 7$ is a member (Kaper et al., 2004; Torres et al., 2005). E.coli is commonly used as surrogate indicator; its presence in food generally indicates direct and indirect fecal contamination (Clarence et al., 2009). Therefore, this study was planned out to evaluate the bacteriological status of meat products ((beefburger and kofta) by isolation and identification of Escherichia coli from examined samples of meat products (beef burger and kofta) and detection of antibiotic sensitivity of isolated strains of E. coli.

\section{MATERIAL AND METHODS}




\subsection{Collection of samples}

One hundred random samples of meat products represented by beef burger and kofta (50 of each) were collected from different shops at various localities in Menofia governorate. Samples was kept in a separated sterile plastic bag and preserved in an ice box. All samples were subjected to the bacteriological examinations to evaluate their quality from bacteriological standpoint of view.

\subsection{Isolation and identification of E. coli}

The technique recommended by ISO, (2004) by using Eosin Methylene Blue (EMB) agar media. Suspected colonies for E. coli were morphologically and biochemically identified.

\subsection{Serotyping of E. coli}

E. coli isolates were serologically identified according to Kok et al. (1996) by using rapid diagnostic $E$. coli antisera sets DENKA SEIKEN Co., Japan for diagnosis of the Enteropathogenic types.

\subsection{Antibiogramme for antibiotic sensitivity of isolated strains of E. coli}

Antimicrobial susceptibility was tested by the single diffusion method according to Mary and Usha (2013) for E. coli. Sensitivity discs with variable concentrations were used to determine the susceptibility of the isolated E. coli strains (Oxoid Limited, Basingstoke, Hampshire, UK).

\section{RESULTS}

Result achieved in table (1) indicated that the incidence of $E$. coli in the examined samples of meat products were $28 \%$ and $36 \%$ for beef burger and kofta, respectively. Also, data in table (1) revealed that the serologically identified E. coli isolates in the examined samples of beef burger were $\mathrm{O}_{26}: \mathrm{H}_{11}(8 \%), \mathrm{O}_{86}(2 \%), \mathrm{O}_{111}: \mathrm{H}_{4}(4 \%), \mathrm{O}_{119}$ $: H_{4}(2 \%), O_{124}(4 \%), O_{125}: H_{21}(6 \%)$ and $\mathrm{O}_{167}: H_{21}(2 \%)$, while in the examined samples of kofta $\mathrm{O}_{26}: \mathrm{H}_{11}(6 \%), \mathrm{O}_{55}: \mathrm{H}_{7}(6$ $\%), \mathrm{O}_{104}: \mathrm{H}_{4}(2 \%), \mathrm{O}_{111}: \mathrm{H}_{4}(10 \%)$,

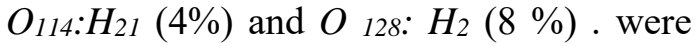
identified.

Table (1): Incidence of E. coli in examined samples of meat products

\begin{tabular}{|c|c|c|c|c|c|}
\hline \multirow[t]{2}{*}{$\begin{array}{l}\text { E. coli } \\
\text { Strains }\end{array}$} & \multicolumn{2}{|c|}{$\begin{array}{l}\text { Beef } \\
\text { burger }\end{array}$} & \multicolumn{2}{|c|}{ Kofta } & \multirow[t]{2}{*}{ Strain } \\
\hline & No. & $\%$ & No. & $\%$ & \\
\hline O26: H11 & 4 & 8 & 3 & 6 & EHEC \\
\hline O55 : H7 & 0 & 0 & 3 & 6 & EPEC \\
\hline O86 & 1 & 2 & 0 & 0 & EPEC \\
\hline O104 : H4 & 0 & 0 & 1 & 2 & EPEC \\
\hline O114 : H21 & 0 & 0 & 2 & 4 & EPEC \\
\hline O111: H4 & 2 & 4 & 5 & 10 & EHEC \\
\hline O119 : H4 & 1 & 2 & 0 & 0 & EPEC \\
\hline $\mathrm{O} 124$ & 2 & 4 & 0 & 0 & EIEC \\
\hline $\mathrm{O} 125$ : H21 & 3 & 6 & 0 & 0 & ETEC \\
\hline O128 : H2 & 0 & 0 & 4 & 8 & ETEC \\
\hline O167 : H21 & 1 & 2 & 0 & 0 & EPEC \\
\hline Total & 14 & 28 & 18 & 36 & \\
\hline
\end{tabular}

Table (2): Percentages of Antimicrobial susceptibility of $E$. coli strains isolated from the examined samples of meat products $(n=32)$

\begin{tabular}{lcccccc}
\hline Agents & \multicolumn{2}{c}{ S } & \multicolumn{3}{c}{ I } & \multicolumn{2}{c}{ R } \\
& No. & $\%$ & No. & $\%$ & No. & $\%$ \\
\hline E & - & - & - & - & 30 & 100 \\
AMX & - & - & 1 & - & 30 & 100 \\
P & - & - & 2 & 6.7 & 28 & 93.3 \\
AM & 1 & 3.1 & 3 & 10.0 & 26 & 86.7 \\
S & 2 & 6.2 & 7 & 23.3 & 21 & 70.0 \\
SXT & 5 & 15.6 & 8 & 30.0 & 17 & 56.7 \\
NA & 6 & 18.8 & 8 & 33.3 & 16 & 53.3 \\
T & 8 & 25.0 & 10 & 30.0 & 15 & 50.0 \\
NOR & 13 & 40.6 & 10 & 26.7 & 13 & 43.3 \\
C & 15 & 46.9 & 9 & 16.7 & 12 & 40.0 \\
CP & 20 & 62.5 & 5 & 20.0 & 8 & 26.7 \\
K & 21 & 65.6 & 5 & 13.3 & 5 & 16.7 \\
N & 24 & 75.0 & 3 & 16.7 & 3 & 10.0 \\
G & 29 & 90.6 & 2 & 3.33 & 2 & 6.7 \\
\hline E (Erythromycin), & AMX & \multicolumn{3}{c}{ (Amoxicillin), P }
\end{tabular}
(Penicillin), AM (Ampicillin), S (Streptomycin), SXT (Sulphamethoxazol), NA (Nalidixic acid), T (Oxytetracycline), NOR (Norfloxacin), C (Chloramphenicol), $\mathrm{CP}$ (Ciprofloxacin), $\mathrm{K}$ (Kanamycin), N (Neomycin), G (Gentamicin)

The results revealed in table (2) that the isolated E. coli strains were highly sensitive to Gentamicin $(\mathrm{G}) 90.6 \%$ Neomycin $(\mathrm{N})$ 75\%, Kanamycin (K) 65.6\%, Chloramphenicol (C) $46.9 \%$ and 
Table (3): Percentages of Antimicrobial susceptibility of E. coli strains isolated from the examined samples of meat products $(n=32)$

\begin{tabular}{|c|c|c|c|}
\hline No & $\begin{array}{c}\text { E. coli } \\
\text { serovars }\end{array}$ & Antimicrobial resistance profile & $\begin{array}{l}\text { MAR } \\
\text { index }\end{array}$ \\
\hline 1 & O26: H11 & E, AMX, P, AM, S, SXT, NA, T, NOR, C, CP, K, N & 0.928 \\
\hline 2 & $\mathrm{O} 26: \mathrm{H} 11$ & E, AMX, P, AM, S, SXT, NA, T, NOR, C, CP & 0.786 \\
\hline 3 & $\mathrm{O} 26: \mathrm{H} 11$ & E, AMX, P, AM, S, SXT, NA, T & 0.571 \\
\hline 4 & $\mathrm{O} 26: \mathrm{H} 11$ & E, AMX, P, AM, S, SXT & 0.428 \\
\hline 5 & $\mathrm{O} 26: \mathrm{H} 11$ & $\mathrm{E}, \mathrm{AMX}, \mathrm{P}, \mathrm{AM}, \mathrm{S}$ & 0.357 \\
\hline 6 & $\mathrm{O} 26: \mathrm{H} 11$ & $\mathrm{E}, \mathrm{AMX}, \mathrm{P}, \mathrm{AM}$ & 0.286 \\
\hline 7 & $\mathrm{O} 26: \mathrm{H} 11$ & $\mathrm{E}$ & 0.071 \\
\hline 8 & $\mathrm{O} 111: \mathrm{H} 2$ & E, AMX, P, AM, S, SXT, NA, T, NOR, C, CP, K, N, G & 1.000 \\
\hline 9 & $\mathrm{O} 111: \mathrm{H} 2$ & E, AMX, P, AM, S, SXT, NA, T, NOR, C, CP, K, N & 0.928 \\
\hline 10 & $\mathrm{O} 111: \mathrm{H} 2$ & E, AMX, P, AM, S, SXT, NA, T, NOR & 0.643 \\
\hline 11 & $\mathrm{O} 111: \mathrm{H} 2$ & E, AMX, P, AM, S, SXT, NA, T & 0.571 \\
\hline 12 & $\mathrm{O} 111: \mathrm{H} 2$ & E, AMX, P, AM, S, SXT, NA & 0.500 \\
\hline 13 & $\mathrm{O} 111: \mathrm{H} 2$ & $\mathrm{E}, \mathrm{AMX}, \mathrm{P}, \mathrm{AM}$ & 0.286 \\
\hline 14 & $\mathrm{O} 111: \mathrm{H} 2$ & $\mathrm{E}, \mathrm{AMX}, \mathrm{P}$ & 0.214 \\
\hline 15 & $\mathrm{O} 128: \mathrm{H} 2$ & E, AMX, P, AM, S, SXT, NA, T, NOR, C, CP, K, N & 0.928 \\
\hline 16 & $\mathrm{O} 128: \mathrm{H} 2$ & E, AMX, P, AM, S, SXT, NA, T, NOR, C & 0.714 \\
\hline 17 & $\mathrm{O} 128: \mathrm{H} 2$ & E, AMX, P, AM, S & 0.357 \\
\hline 18 & $\mathrm{O} 128: \mathrm{H} 2$ & $\mathrm{E}, \mathrm{AMX}$ & 0.143 \\
\hline 19 & $\mathrm{O} 55: \mathrm{H} 7$ & E, AMX, P, AM, S, SXT, NA, T, NOR, C, CP, K & 0.857 \\
\hline 20 & O55 : H7 & E, AMX, P, AM, S, SXT, NA, T & 0.571 \\
\hline 21 & $\mathrm{O} 55: \mathrm{H} 7$ & E, AMX, P, AM, S, SXT, NA & 0.286 \\
\hline 22 & $\mathrm{O} 125: \mathrm{H} 21$ & E, AMX, P, AM, S, SXT, NA, T, NOR, C, CP, K, N & 0.714 \\
\hline 23 & $\mathrm{O} 125: \mathrm{H} 21$ & E, AMX, P, AM, S, SXT, NA & 0.500 \\
\hline 24 & $\mathrm{O} 125: \mathrm{H} 21$ & E, AMX, P, AM & 0.286 \\
\hline 25 & $\mathrm{O} 114: \mathrm{H} 21$ & E, AMX, P, AM, S, SXT, NA, T & 0.571 \\
\hline 26 & $\mathrm{O} 114: \mathrm{H} 21$ & E, AMX, P, AM & 0.286 \\
\hline 27 & $\mathrm{O} 124$ & $\mathrm{E}, \mathrm{AMX}, \mathrm{P}, \mathrm{AM}, \mathrm{S}, \mathrm{SXT}, \mathrm{NA}, \mathrm{T}$ & 0.357 \\
\hline 28 & $\mathrm{O} 124$ & $\mathrm{E}, \mathrm{AMX}, \mathrm{P}, \mathrm{AM}, \mathrm{S}$ & 0.286 \\
\hline 29 & O86 & $\mathrm{E}, \mathrm{AMX}, \mathrm{P}, \mathrm{AM}, \mathrm{S}$ & 0.286 \\
\hline 30 & O104 & E, AMX, P, AM, SXT, NA & 0.500 \\
\hline 31 & $\mathrm{O} 119: \mathrm{H} 4$ & $\mathrm{E}, \mathrm{AMX}, \mathrm{P}, \mathrm{AM}$ & 0.286 \\
\hline 32 & $\mathrm{O} 167: \mathrm{H} 21$ & E, AMX, P & 0.143 \\
\hline \multicolumn{3}{|r|}{ Average } & 0.515 \\
\hline
\end{tabular}

Ciprofloxacin (CP) $62.5 \%$. On the other hand, were resistant to Erythromycin (E) 100\%, Amoxicillin (AMX) 96.9\%, Penicillin (P) 93.8\%, Ampicillin (AM) $87.5 \%$. Streptomycin (S) 71.9\%, on contrast E. coli strains were Application of sensitivity test on all E. Coli Strains indicated that most of them were multiple antimicrobial resistance (MAR) where the MAR index equal 0.515 as shown in table (3).

\section{DISCUSSION}

The presence of $E$. coli in contaminated food products is commonly attributed to fecal contamination when they are improperly handled and/or when inactivation treatments fail. The adaptation of E. coli at low $\mathrm{pH}$ and low levels can vary at different temperatures depending on the serotype (Valero et al., 2010). The current results for the examined samples of kofta were nearly similar to those obtained by Abdalla and Hassan (2000) (40\%), Torky (2004) (30\%), and shawish (2015) (36\%), but lower than those obtained by Hazarika 
et al. (2007) (27.6\%), Nadim (2016) (28\%). On the other hand, higher result was obtained by El-Mossalami (2003) (50\%). While, the current results for the examined samples of beef burger were higher than those obtained by Fathi et al. (1994) $(77.78 \%)$ and El-Mossalami (2003) (35\%) and lower than those obtained by Gomez et al. (2002) (8.8\%), El-Sherif (2009) (10\%) and El-Dosoky et al. (2013) (10\%), but similar to those obtained by ouf (2001) (30\%), shawish (2015) (28\%) and Nadim (2016) (24\%). Regarding to these results we could conclude that variation between results of kofta and beef burger this might be mainly attributed to the manner of handling each product, the number of processing operations that the product subjected to them, amount of post processing contamination and storage condition and shelf life of each product.

\section{REFERENCES}

Abdallah, W, Hassan, A.A. 2000. Sanitary status of some ready to eat meat meals in Cairo and Giza Governorates. J. Egypt. Vet. Med., Assuit, 60(7): 95.

Clarence, S.Y., Nwinyi, O., Chinedu, S.N. 2009. Assessment of bacteriological quality of ready to eat food (Meat pie) in Benin City metropolis, Nigeria. African Journal of Microbiology Research, 3(6): 390-395.

El-Dosoky, H.F.A., Shafik, S., Baher, M.W. 2013. Detection of spoilage and food poisoning bacteria in some ready to eat meat products in Dakahlia Governorate. Assiut Vet. Med. J., 59(138).

El-Mossalami Eman, I.K. 2003. Risk assessment of ready prepared meat products. Ph. D. Thesis, (Meat Hygiene), Fac. Vet. Med., Cairo. Univ.

El-Sherif, Amal. M. 2009. Different serotypes of E. coli and Salmonellae in some Meat Products and their behavior during different heat treatments and cold storage. Ph. D.
Thesis Fac. Vet. Med. Cairo. Univ.

Fathi,S., EL-Kateib, T., Mostafa, S., Hassanin, K. 1994. Salmonella and Enteropathogenic Escherichia coli in some locally manufactured meat products. Assiut Vet Med. J., 31: 190.

Gómez, D., Miliwebsky, E., Fernández, P.C., Baschkier, A., Manfredi, E., Zotta, M., Nario, F., Piquín, A., Sanz, M., Etcheverría, A., Padola, N., Parma, A., Rivas, M. 2002. Isolation and characterization of Shiga-toxinproducing Escherichia coli from frozen hamburgers and soft cheeses. Rev. Argent. Microbiol., 34(2):66.

Hazarika, R.A., Singh, D.K., Kapoor, K.N., Agarwal, R.K., Pandey, A.B., Purusottam, P. 2007. Verotoxic Escherichia coli (STEC) from beef and its products. Indian J. Exp. Biol. 45(2):207.

Kaper, J.B., Nataro, J.P., Mobley H.L.T. 2004. Pathogenic Escherichia coli. Nature Rev.; 2: 123 - 140.

Kok, T., Worswich, D., Gowans, E. 1996. Some serological techniques for microbial and viral infections. In Practical Medical Microbiology (Collee, J.; Fraser, A.; Marmion, B. and Simmons, A., eds.), 14 ${ }^{\text {th }}$ ed., Edinburgh, Churchill Livingstone, UK.

Malik, K., Memona, H. 2010. Molecular and immunological studies of pathogenic Escherichia coli in meat samples collected from different localities of Lahore. International Journal of Cell \& Molecular Biology (IJCMB) 1(3):218-224.

Mary, C., Usha, M. 2013. Incidences of multi-drug resistance Escherichia coli isolates in Panipuri sold in Bangalore. Inter. Food Res. J., 20 (2): 10071009.

Nadim, Samaa, S. 2016. "Acomparative study on application of PCR and ELISA for detection of pathogens in some meat products with special references to public health".Ph.D.Thesis (Meat Hygiene)., 
Fac .Vet. Med., Benha Univ.

Ouf Jehan., M. M. 2001. Microorganisms of sanitary importance in some meat products and their additives. Ph.D. Thesis, Fac. Vet. Med. Cairo. Univ.

Saleh, E.A., El- Maghraby, M.A., Amer. W.N. 2012. Sanitary Status of Meat Processing Plants on Some Meat Products Alex. Vet. Med. J., 37(1):916.

Shawish, R.R.M. 2015. "Prevalence of shiga toxin-producing Escherichia coli in some beef products". Ph.D. Thesis (Meat Hygiene),, Fac. Vet. Med., Menoufia Univ.

Torky, Amal, A.S. 2004. Trials for inhibition of some food poisoning microorganisms in meat products. $\mathrm{Ph}$. D. Thesis, Fac. Vet. Med., Cairo Univ.

Torres, A.G., Zhou, Kaper, J. B. 2005. Adherence of diarrheagenic Escherichia coli strains to epithelial cells. Infect. Imm.; 73: 18 - 29.

Valero, A., Rodrígueza, M., Carrascoa, E., Pérez-Rodrígueza, F., García Gimenoa, R.M., Zurera, G. 2010. Studying the growth boundary and subsequent time to growth of pathogenic Escherichia coli serotypes by turbidity measurements. Food Microbiology, 27 (6): 819. 